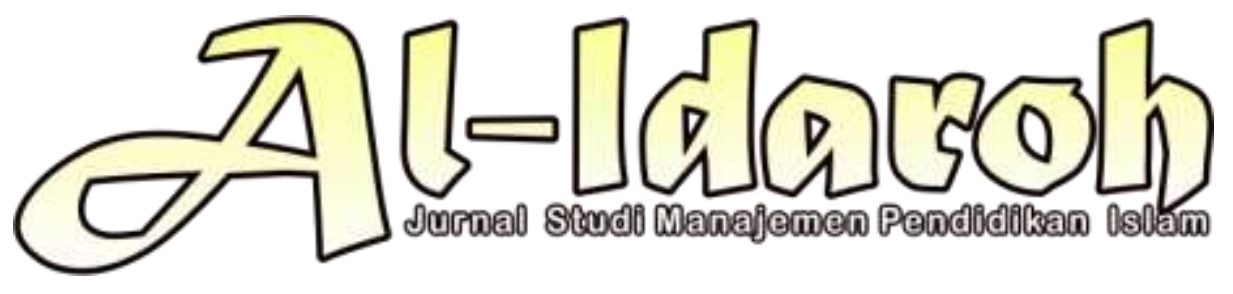

\title{
KONTRIBUSI MANAJEMEN PESERTA DIDIK TERHADAP PENDIDIKAN SEKSUAL
}

\author{
Minggusta Juliadarma \\ Institut Agama Islam Negeri Ternate \\ Email: minggustajuliadarma@,iain-ternate.ac.id
}

\begin{abstract}
Abstrak: So far, education experts have contributed a lot of thoughts on tips on child sexual education, but the operation of the education process is only through informal education, which is only in the family environment. This study seeks to present the flow of the sexual education process of children at the school level as an integral part of the learning process. This study discusses the contribution of student management to sexual education of children in schools. This study uses library research methods and uses documentation study as a data collection technique. The results revealed that the process of implementing sexual education in students can be carried out in three stages of activities, namely the stages of admitting new students, the learning process, guidance and monitoring. The first stage is through managing new student orientation activities which are divided into male and female groups, new students are accustomed not to mingle with the opposite sex. This activity should also be used by the school to socialize school rules that contain sexual education values. The second stage, management of the learning process in the form of managing student groupings based on gender (gender grouping); determining the learning method through the expository method, discussion method, exemplary method, and babituation method; as well as managing learning programs by incorporating sexual education values into formal subjects such as Biology, Sociology, Morals, and Fiqh. The next stage is to carry out structured guidance related to sexual education coaching under the supervision of guidance and counseling teachers. The final stage in the series of sexual education processes in schools is monitoring activities that involve all stakeholders in the school environment such as the principal, vice principal in student affairs, homeroom teachers, subject teachers, guidance and counseling teachers and even parents.
\end{abstract}

Keyword: Student Management, Child Sexual Education

Al-Idaroh: Jurnal Studi Manajemen Pendidikan Islam

Volume 5 Nomor 1 Maret 2021; p-ISSN: 2549-8339; e-ISSN: 2579-3683 


\section{Pendahuluan}

Pendidikan Islam merupakan pendidikan yang dilandasi oleh ajaran Islam, karena bersumber dari Al-Qur'an, sunnah, dan pendapat (qaul) ulama'. Pendidikan Islam menempatkan manusia sebagai salah satu ciptaan Allah SWT. Oleh karena itu, manusia diposisikan sebagai objek dan juga subjek pendidikan yang tidak bebas nilai. Kehidupannya diatur dengan tuntunan wahyu dan nilai-nilai keIslaman. Komponen penting dalam bingkai sistem pendidikan Islam adalah peserta didik (siswa). Tujuan pendidikan Islam akan lebih mudah tercapai jika komponen ini saling berinteraksi dengan pengelola pendidikan dalam proses pembelajaran.

Manajemen pendidikan memiliki peranan penting dalam mengelola peserta didik. Ditinjau dari ruang lingkupnya, manajemen peserta didik merupakan salah satu objek pengelolaan dari manajemen pendidikan Islam. Dalam perspektif pendidikan Islam, peserta didik disebut dengan berbagai istilah, diantaranya adalah muta'allim (orang yang sedang belajar), mutarabbi (orang yang dididik), dan muta'addib (orang yang belajar adab). Jadi, manajemen pendidikan Islam tidak hanya mengatur tentang pengelolaan proses pembelajaran peserta didik saja, tetapi juga menciptakan dan mengelola lingkungan pendidikan yang kondusif bagi peserta didik untuk membentuk pribadi muslim yang memiliki akblaqul kariimah (tingkah laku yang baik).

Realita yang terjadi menunjukkan bahwa mengelola peserta didik bukanlah tugas yang mudah. Mengelola komponen ini akan menghadapkan pada berbagai problematika yang pelik. Salah satu problematika tersebut berkaitan dengan permasalahan seksual anak. Permasalahan ini bersumber dari diri peserta didik sendiri dan juga dalam kasus tertentu anaklah yang menjadi korban dari pihak lain. Beberapa contoh yang mengemuka terkait dengan permasalahan seksual anak ini diantaranya kasus transvetitisme (anak laki-laki berpakaian seperti wanita atau sebaliknya), voyeurisme (ketertarikan mengintip lawan jenis), membaca dan menyaksikan hal-hal yang berbau pornografi melalui berbagai media/perangkat, melakukan pelecehan seksual terhadap teman sekolah, melakukan perbuatan zina, korban kasus pedofilia, dsb.

Contoh kasus-kasus tersebut kerap terjadi di lingkungan sekolah sehingga pemberitaannya sering dipublikasi oleh media massa. Ironis mengingat sekolah sebagai tempat yang seharusnya suci dari hal-hal negatif tersebut. Merespon fenomena tersebut, sebenarnya pendidikan Islam memiliki formula khusus sebagai 
tindakan preventif terkait permasalahan seksual anak tersebut. Menurut perspektif pendidikan Islam, Allah SWT menciptakan dorongan seksual pada jiwa setiap manusia apabila telah tiba masanya. Masa ini dinamakan masa taklif. Apabila seorang anak telah memasuki masa tersebut, maka ia memiliki tanggungjawab terhadap hasrat seksualnya. Islam memelihara dan menjaga anak dengan perintah dan larangan. Tuntutan ini agar dorongan seksual yang ada pada diri anak dapat dikendalikan dengan normal, tanpa ada faktor eksternal yang menyebabkannya menyimpang.

Penelitian ini sangat penting untuk dikaji lebih mendalam karena selama ini para ahli pendidikan Islam banyak memberikan kontribusi pemikiran tentang kiat-kiat pendidikan seksual anak, namun operasional dari proses pendidikan tersebut hanya melalui pendidikan informal, yaitu hanya di lingkungan keluarga saja. Penelitian ini berusaha menampilkan alur proses pendidikan seksual anak di tingkat sekolah sebagai salah satu bagian integral dari proses pembelajaran. Penelitian ini merupakan penelitian kualitatif dengan menerapkan metode penelitian pustaka (library research) yang diambil dari berbagai sumber literatur untuk mendapatkan data. Sedangkan teknik pengumpulan data yang digunakan dalam penelitian ini adalah teknik dokumentasi.

\section{Pembahasan}

A. Manajemen Peserta Didik

Manajemen peserta didik adalah usaha pengelolaan siswa dimulai sejak peserta didik masuk sekolah hingga keluar (tamat) dengan memberikan pelayanan yang terarah, teratur, dan terkontrol agar tercipta kelangsungan dan peningkatan mutu. ${ }^{1}$ Pengertian tersebut mengandung makna bahwa untuk menciptakan sumber daya manusia yang potensial dan bermanfaat bagi masyarakat, diperlukan usaha pengelolaan dan perbaikan dari lembaga pendidikan.

Tujuan manajemen peserta didik untuk mengelola berbagai kegiatan yang berkaitan dengan peserta didik agar proses pembelajaran yang diselenggarakan sekolah dapat berjalan dengan tertib, teratur, dan mampu merealisasikan tujuan

\footnotetext{
${ }^{1}$ Sri Minarti, Manajemen Sekolab; Mengelola Lembaga Pendidikan Secara Mandiri, (Yogyakarta: Ar-Ruzz Media, 2012), 159
} 
pendidikan. ${ }^{2}$ Tujuan tersebut membutuhkan dimensi waktu yang relatif panjang, sehingga manajemen peserta didik tidak selalu mengenai pengelolaan peserta didik saat mereka mengikuti rangkaian proses pembelajaran di sekolah, namun juga saat mereka akan keluar guna melanjutkan pendidikan ke jenjang yang lebih tinggi, bahkan jika mereka memutuskan untuk langsung terjun ke dalam lapangan pekerjaan.

Oleh karena itu, berdasarkan pengertian dan tujuan manajemen peserta didik di atas, manajemen peserta didik memiliki empat tahapan kegiatan, yaitu tahapan penerimaan peserta didik baru, proses pembelajaran, bimbingan, dan monitoring. Seluruh tahapan kegiatan tersebut memerlukan pengelolaan yang maksimal untuk meraih hasil yang memuaskan.

Tahapan kegiatan penerimaan peserta didik baru dapat ditempuh melalui berbagai pendekatan, diantaranya melalui pendekatan formal ditempuh dengan cara mendistribusikan brosur, memasang baliho dan spanduk, dan iklan di radio dan televisi. Pendekatan sosial ditempuh melalui kegiatan-kegiatan peduli sosial terhadap masyarakat yang diselenggarakan oleh sekolah sebagai wujud pengabdian kepada masyarakat. Pendekatan kultural ditempuh melalui penyesuaian kultur/budaya masyarakat sekitar agar dapat melebur dan menarik minat masyarakat sekitar terhadap eksistensi sekolah tersebut. Pendekatan rasionalprofesional ditempuh melalui kegiatan mempromosikan berbagai prestasi dan keunggulan sekolah tersebut kepada khalayak. Pendekatan ideologis ditempuh melalui penggunaan istilah-istilah keIslaman untuk menentukan lembaga pendidikan yang dipilih oleh umat Islam. ${ }^{3}$

Proses pembelajaran merupakan tahapan kegiatan inti dalam manajemen peserta didik. Sekolah diberi keleluasaan dalam mengaplikasikan berbagai metode dan strategi pembelajaran yang paling efektif dan efisien disesuaikan dengan karakteristik mata pelajaran, kemampuan peserta didik, kapabilitas paedagogik guru, dan ketersediaan sarana dan prasarana pembelajaran. ${ }^{4}$ Pengelolaan proses

\footnotetext{
${ }^{2}$ Mujamil Qomar, Manajemen Pendidikan Islam; Strategi Baru Pengelolaan Lembaga Pendidikan Islam, (Jakarta: Erlangga, 2017), 142

${ }^{3}$ Ibid, 144-145

${ }^{4}$ Departemen Pendidikan Nasional Republik Indonesia, Manajemen Peningkatan Mutu Berbasis Sekolah, (Jakarta: Direktorat SLTP, 2001), 22
} 
pembelajaran merupakan pemberdayaan peserta didik melalui proses interaksi antara perilaku pendidik dan perilaku peserta didik baik di dalam kelas maupun di luar kelas. ${ }^{5}$ Jadi, titik tekan proses pembelajaran tidak hanya sekedar penguasaan ilmu pengetahuan semata, namun juga pada aspek perubahan perilaku peserta didik. Terdapat beberapa langkah kegiatan dalam pengelolaan proses pembelajaran, yaitu (1) Pengelompokan siswa secara heterogen atau homogen; (2) Penentuan program pembelajaran; (3) Pembinaan disiplin dan partisipasi peserta didik dalam kegiatan pembelajaran; (4) Pembinaa program ekstrakurikuler; (5) Penentuan hasil prestasi belajar. ${ }^{6}$

Tahapan selanjutnya adalah sekolah memberikan bimbingan kepada peserta didik. Bimbingan yang dimaksud adalah memberikan bimbingan dan bantuan kepada peserta didik yang memiliki permasalahan dalam belajar, emosional, dan permasalahan sosial sehingga dapat menemukan jalan keluar dari permasalahan tersebut menuju tumbuh kembang secara maksimal sesuai dengan potensi yang dimiliki. ${ }^{7}$ Pihak sekolah harus membuat perencanaan yang tepat terkait program bimbingan peserta didik. Keberhasilan program bimbingan ini tidak hanya ketepatan dalam menyusun proram bimbingan, tetapi juga kemampuan sekolah dalam menyediakan sumber daya professional di bidang konseling. Sedangkan tahapan kegiatan terakhir dalam manajemen peserta didik adalah melaksanakan monitoring. Pelaksanaan monitoring ini sudah seharusnya menjadi program rutin sekolah agar keseluruhan kegiatan manajerial peserta didik yang telah dilaksanakan dapat dipantau perkembangannya. Berhasil tidaknya pengelolaan peserta didik akan terpantau jika sekolah secara rutin melaksanakan kegiatan monitoring.

Peserta didik merupakan komponen utama dalam sistem pendidikan. Untuk itu, peserta didik dapat ditinjau dari berbagai pendekatan, yaitu:

1. Pendekatan sosial, peserta didik ditanamkan nilai-nilai sosial secara bertahap dan berjenjang melalui proses pembelajaran dan pengalaman langsung, dimulai

${ }^{5}$ Syaiful Sagala, Administrasi Pendidikan Kontemporer, (Bandung: Alfabeta, 2009), 5

${ }^{6}$ Mujamil Qomar, Manajemen Pendidikan Islam; Strategi Baru Pengelolaan Lembaga Pendidikan Islam, (Jakarta: Erlangga, 2017), 145

${ }^{7}$ E. Mulyasa, Manajemen Berbasis Sekolah; Konsep, Strategi, dan implementasi. (Bandung: Rosdakarya, 2004), 47 
dari lingkungan keluarga sampai di lingkungan masyarakat sekolah. Proses diharapkan peserta didik mampu menyesuaikan diri dengan lingkungannya.

2. Pendekatan psikologis, potensi-potensi yang dimiliki peserta didik terkait minat dan bakat dikembangakan melalui proses pendidikan dan pembelajaran di sekolah. Perkembangan ini menggambarkan perubahan kualitas dan kemampuan dalam diri peserta didik.

3. Pendekatan edukatif, pendekatan ini memposisikan peserta didik sebagai komponen penting yang mempunyai hak dan kewajiban dalam sistem pendidikan yang komprehensif dan terpadu. ${ }^{8}$

Setiap peserta didik memiliki latar belakang yang berbeda-beda. Diantara bentuk perbedaan peserta didik tersebut diantaranya adalah perbedaan kecerdasan (intelligence), bakat (aptitude), keadaan jasmaniyah (physical fitness), latar belakang keluarga (bome background), hasil belajar (academic achievement), ${ }^{9}$ jenis kelamin (gender), dan gaya belajar (learning style). ${ }^{10}$ Perbedaan-perbedaan tersebut akan mempengaruhi proses pembelajaran di kelas. Maka, manajemen pendidikan memiliki peranan dalam mengidentifikasi bentuk-bentuk perbedaan yang dimiliki masing-masing peserta didik. Dengan mengetahui berbagai perbedaan individu itu, diharapkan dapat membantu proses pembelajaran yang efektif dan efisien.

Adanya perbedaan-perbedaan pada diri peserta didik melahirkan pemikiran untuk mengelompokkan peserta didik pada kelompok yang berbeda di kelas. Dalam istilah manajemen pendidikan pengelompokan kelas tersebut dikenal dengan istilah grouping. Pengelompokan ini tidak bermaksud untuk mendiskriminasi peserta didik, namun justru untuk membantu mereka supaya bisa berkembang semaksimal mungkin sesuai dengan potensi yang dimiliki.

Berikut ini adalah macam-macam pengelompokan peserta didik: ${ }^{11}$

a. Friendship grouping, pengelompokan berdasarkan kesukaan dalam pertemanan.

b. Achievement grouping, pengelompokan berdasarkan prestasi akademik.

c. Aptitude grouping, pengelompokan berdasarkan bakat peserta didik.

\footnotetext{
${ }^{8}$ Sunarto dan Agung Hartono, Perkembangan Peserta Didik, (Jakarta: Rineka Cipta, 2008), 11-17

${ }^{9}$ Muhammad Irham, Novan Ardi Wiyani, Psikologi Pendidikan; Teori dan Aplikasi dalam Proses Pembelajaran, (Yogyakarta: Ar-Ruzz Media, 2015), 77

${ }^{10}$ Sugihartono, Psikologi Pendidikan, (Yogyakarta: UNY Press, 2007), 34-60

11 Suruni, Manajemen Pendidikan, (Bandung: Alfabeta, 2009), 211
} 


\section{Kontribusi Manajemen Peserta Didik Terhadap Pendidikan Seksual}

d. Interest grouping, pengelompokan berdasarkan minat yang dilandasi kesenangan.

e. Intelligence grouping, pengelompokan berdasarkan hasil tes kecerdasan (intelegensi).

Selain itu, pengelompokan juga didasarkan pada kesamaan yang ada pada peserta didik, yaitu persamaan jenis kelamin, dan usia. ${ }^{12}$ Dengan demikian berdasarkan elaborasi di atas, sistem klasifikasi peserta didik merupakan cara untuk mengelompokkan peserta didik berdasarkan kriteria-kriteria tertentu. Adanya pengaturan pengelompokan ini diharapkan sekolah dapat meningkatkan mutu proses pembelajaran di kelas yang tentunya akan berdampak positif pada peserta didik.

B. Pendidikan Seksual

Pendidikan seksual yang menjadi pokok pembahasan dalam penelitian ini adalah pendidikan seksual menurut perspektif pendidikan Islam, sehingga akan didapati berbagai istilah keIslaman yang diungkapkan oleh ahli-ahli pendidikan Islam. Istilah pendidikan secara etimologis dalam bahasa Arab dikenal dengan istilah tarbiyah, berasal dari akar kata rabba-yarubbu-tarbiyatan yang artinya mendidik, mengasuh, dan memelihara. ${ }^{13}$ Sedangkan istilah seks dalam bahasa arab dikenal dengan istilah al-jins, berasal dari akar kata janasa-yajnusu-jansan dengan arti jenis kelamin. ${ }^{14}$ Jadi, pendidikan seksual dalam pendidikan Islam dikenal dengan istilah tarbiyat al-jinsiyyah.

Pengertian pendidikan seksual banyak dijelaskan oleh berbagai pakar pendidikan Islam, diantaranya diungkapkan oleh Abdullah Nashih 'Ulwan, pendidikan seksual adalah upaya penjelasan, pengajaran, dan pemahaman kepada anak terkait permasalahan seksual dimulai sejak anak telah mengenal permasalahan seputar naluri seksual dan perkawinan. Saat anak tumbuh berkembang menjadi seorang remaja dan telah mengerti urusan kehidupan, ia telah memahami hal-hal yang diharamkan dan hal-hal yang dihalalkan. Bahkan anak memiliki kemampuan

\footnotetext{
12 Badrudin, Manajemen Peserta Didik, (Jakarta: Indeks, 2014), 40

13 Ahmad Warson Al-Munawwir, Kamus Al-Munawwir Arab-Indonesia Terlengkap, (Yogyakarta: Pustaka Progresif, 1997), 504

${ }^{14}$ Ibid, 214
} 
dalam mengaplikasikan tingkah laku yang Islami, tidak tenggelam dalam syahwat, dan tidak terjebak gaya hidup cinta terhadap dunia. ${ }^{15}$

Menurut Utsman ath-Thawil, pendidikan seksual adalah mengajarkan dan memberi pengertian kepada anak sejak memasuki usia baligh tentang permasalahan yang berkaitan dengan seks, perkawinan, dan naluri. Sehingga saat anak menjadi remaja, ia tidak akan terjerumus ke dalam hawa nafsunya, dan menghindarkan diri dari perbuatan menghalalkan segala cara untuk mencapai tujuannya. ${ }^{16}$ Sedangkan menurut Muhammad Bukhori, pendidikan seksual adalah pendidikan yang memiliki objek khusus di bidang perkelaminan secara komprehensif. ${ }^{17}$ Muhammad Suwaid menjelaskan pengertian pendidikan seks yaitu upaya penjagaan terhadap dorongan seksual pada anak dengan pemberian perintah dan larangan syara' agar perkembangan seksual anak tumbuh normal tanpa ada faktor eksternal yang membuatnya menyimpang dari perilaku yang baik. ${ }^{18}$

Jadi, berdasarkan berbagai penjelasan dari para ahli pendidikan Islam tersebut, dapat disimpulkan bahwa pendidikan seksual ialah berbagai upaya pengajaran, penjelasan, pemahaman, dan bimbingan kepada anak sejak usia baligh tentang segala hal yang berkaitan dengan seks yang diharapkan ketika tumbuh menjadi remaja akan memiliki akhlak yang baik dan dapat mengendalikan hasrat seksualnya.

Banyak kalangan berasumsi bahwa permasalahan seksual ini merupakan wilayah orang dewasa yang tidak selayaknya dikonsumsi oleh anak-anak. Seringkali permasalahan seksual dianggap sesuatu yang tabu, jorok, dan tidak pantas untuk diperbincangkan, bahkan di ranah akademik. Diskursus tentang pendidikan seksual yang diberikan orang tua kepada anak seringkali sengaja disalahkan dan celakanya kondisi tersebut dimulai ketika anak masih usia dini.

Namun semua argumentasi tersebut dapat dipatahkan mengingat permasalahan seksual yang diperbincangkan di ranah pendidikan Islam berupa tahapan pengajaran, bimbingan, dan pengenalan terkait segala hal yang berkaitan

\footnotetext{
${ }^{15}$ Minggusta Juliadarma, 'Pencegahan Kenakalan Anak Menurut Abdullah Nashih 'Ulwan', Jurnal Istighna, Volume 2, Nomor 2, (Juli 2019), 38-54

16 Utsman Ath-Thawil, Ajaran Islam tentang Fenomena Seksual, (Jakarta: Raja Grafindo Persada, 2000), 11

${ }_{17}$ Muhammad Bukhori, Islam dan Adab Seksual, (Solo: Amzah, 2001), 3

${ }^{18}$ Muhammad Nur Abdul Hafizh Suwaid, Manhaj al-Tarbiyyat al-Nabawiyyat lil ath-Thifl. (Mesir: Daar alWafa' al-Manshurah, 2013), 368
} 
dengan seks, apa yang dihalalkan dan apa yang diharamkan oleh syariat Islam. Setelah melalui pendidikan seksual ini, anak diharapkan memahami dan mengerti bagaimana dia seharusnya menyalurkan naluri itu sesuai dengan yang diperbolehkan oleh ajaran agamanya.

Tujuan diajarkannya pendidikan seksual untuk anak ialah untuk menjaga anak dari berbagai bentuk penyimpangan seksual dan juga agar fitrahnya senantiasa terpelihara, suci, dan bersih tidak dikotori oleh faktor-faktor eksternal yang merusak. ${ }^{19}$ Tujuan tersebut diharapkan agar anak dapat bertingkah laku sesuai dengan tuntunan syariat dan nilai fitrah yang terkandung dalam dirinya. Jika anak salah dalam memahami permasalahan seksualitas, dikhawatirkan terjerumus pada berbagai perbuatan buruk. Oleh karena itu, dalam perspektif Islam, pendidikan seksual masuk dalam kerangka pendidikan akhlak.

Abdullah Nashih Ulwan memetakan fase pendidikan seksual pada anak, yaitu: ${ }^{20}$

a. Usia 7-10 tahun, dinamakan usia tamyiiz: Usia ini anak diajarkan adab meminta izin dan adab melihat. Maksud adab meminta izin adalah orang tua mengajarkan dan membiasakan anak agar meminta izin ketika akan memasuki kamar orang tuanya, sehingga menghindarkan anak dari pemandanganpemandangan yang belum layak dilihat dan didengar. Adapun mksud adab melihat adalah mengajarkan adab melihat lawan jenis kepada anak, agar anak bisa mulai mengenal dan mempraktekkan ajaran menjaga pandangan dalam syariat Islam.

b. Usia 10-14 tahun, dinamakan usia murahaqat, yaitu usia anak hampir mendekati baligh. Usia ini anak anak dijauhkan dari segala hal yang mengarah pada seks. Karena hal itu dapat merangsang syahwat dan merusak akhlaknya.

c. Usia 14-16 tahun, dinamakan usia baligh. Usia ini anak diajarkan tentang aturanaturan fikih saat mereka telah bermimpi, sebagai tanda biologis anak mulai memasuki usia baligh. Di fase ini pendidik mulai boleh menerangkan adab-adab berhubungan seks.

${ }^{19} \mathrm{Ibid}, 370$

${ }^{20}$ Abdullah Nashih Ulwan, Mas'uliyyat al-Tarbiyyah al-Jinsiyyah, (Beirut: Daar al-Salaam, 2010), 5 
d. Usia setelah baligh, dinamakan usia pemuda (adolesesn). Usia ini anak diajarkan tentang adab menjaga kehormatan dan menahan diri saat belum menikah. Metode menjaga kehormatan paling ampuh adalah menikah. Sedangkan cara menahan diri adalah dengan menjaga kemaluan dan mengendalikan hawa nafsu serta mempergiat ibadah, khususnya ibadah puasa.

Mengajarkan pendidikan seksual pada anak tidak dapat dilakukan secara tiba-tiba dan instan, tetapi hendaknya melalui pentahapan pengejaran sejak dini. Berikut adalah hal-hal penting yang dijadikan pedoman bagi para pendidik saat mengajarkan pendidikan seksual, yaitu: ${ }^{21}$

a. Bersikap terbuka dan jujur, ketidakjujuran dan memberikan jawaban sekenanya saja akan mengakibatkan kerusakan logika anak.

b. Bertahap, memperkenalkan hal-hal terkait seks pada anak hendaknya dilakukan secara selangkah demi selangkah dan menyesuaikan jawaban dengan tingkat pemahaman anak.

c. Tidak menganggap permasalahan seksual adalah materi yang besar, berat, dan kotor. Ketika menjelaskan permasalahan seksual pada anak hendaknya pendidik menjelaskannya dengan redaksi tenang dan menjaga intonasi suara, jauhkan persepsi istilah seks bagi orang dewasa yang penuh erotis dan menggugah syahwat.

d. Tidak reaktif/marah yang berlebihan jika ditanya pertanyaan seputar seks oleh anak. Pemahaman anak yang keliru terkait seks adalah saat pendidik menampilkan marah secara berlebihan terhadap pertanyaan anak tentang seks, inilah sebagai pemicu persepsi negatif tentang seks bagi anak.

Upaya memperkenalkan anak dengan permasalahan seksual dimulai dari penjelasan tentang anatomi tubuh, perbedaan jenis kelamin, dan fungsi-fungsi anggota tubuh. ${ }^{22}$ Memberikan penjelasan terkait hal tersebut lambat laun anak dapat mengetahui jika penis dan vagina tidak hanya berfungsi sebagai jalur pembuangan air seni, tetapi juga sebagai alat reproduksi. Setelah anak mengetahui akan fungsi organ tubuhnya, selanjutnya anak diajarkan bagaimana merawat dan

${ }^{21}$ Nurlaili, "Pendidikan Seks Pada Anak", Jurnal Marwah, Volume 10, nomor 1, 2011

22 Ali Mukti, "Pendidikan Seks Untuk. Anak Usia Dini Perspektif Islam”, Jurnal Harkat, Volume 12, nomor 2, 2016, 91-98 
menjaga organ tubuhnya tersebut, bersikap dengan lawan jenis, berperilaku sesuai dengan fitrah jenis kelamin yang dimilikinya sesuai dengan penjelasan ajaran Islam, dan hal yang jauh lebih penting anak mendapatkan penjelasan tentang permasalahan seksual dari orang yang tepat.

C. Kontribusi Manajemen Peserta Didik Terhadap Pendidikan Seksual

Manajemen peserta didik memiliki peranan penting dalam mengawal perkembangan pendidikan seksual anak. Selama ini tanggung jawab pendidikan seksual anak dibebankan kepada orang tua saja, padahal seharusnya mendidik anak membutuhkan peran aktif dua arah, yaitu orang tua dan sekolah sebagai tempat formal anak untuk belajar. Nilai dan ilmu perspektif manajemen pendidikan Islam mempunyai dua kecenderungan, yaitu nilai teoretik dan nilai praktis. ${ }^{23}$ Berkaitan dengan hal tersebut, diskursus aplikasi pendidikan seksual di sekolah seolah luput dielaborasi oleh pakar pendidikan. Selama ini elaborasi teori tentang pendidikan seksual anak hanya sampai di ranah pendidikan keluarga saja. Perlu upaya memadukan kajian teoretik yang sudah ada tersebut untuk dapat diaplikasikan di ranah lembaga pendidikan Islam.

Oleh karena itu, di penelitian ini akan dilakukan elaborasi secara komprehesif terkait bagaimana mengelola peserta didik yang berimplikasi pada perkembangan pendidikan seksual anak di sekolah. Kajian ini memadukan konsep manajemen peserta didik dan pendidikan seksual perspektif pendidikan Islam. Proses pengelolaan peserta didik dalam mengembangakan pendidikan seksual anak mengikuti alur tahapan manajemen peserta didik secara umum, yaitu tahapan penerimaan peserta didik baru, proses pembelajaran, bimbingan dan monitoring. Jadi, pembahasan disajikan secara kronologis dan bertahap.

1. Penerimaan Peserta Didik

Pendidikan seksual pada anak dimulai dari tahapan pertama ini, yaitu sejak anak diterima untuk belajar di sekolah. Salah satu rangkaian kegiatan dalam penerimaan peserta didik baru adalah adanya kegiatan orientasi siswa baru. Tujuan dilaksanakannya orientasi siswa baru ini yaitu forum pengenalan bagi peserta didik baru tentang keadaan-keadaan sekolah, antara lain

${ }^{23}$ Didin Sirojudin dan Hilyah Ashoumi, “Aksiologi Ilmu Pengetabuan Manajemen Pendidikan Islam”, Jurnal Al-Idaroh, Volume 4, Nomor 2, (September 2020), 184-195 
pengenalan tentang tata tertib, kondisi siswa, adaptasi lingkungan sekolah dan pengenalan sekilas mata pelajaran yang akan mereka pelajari, agar peserta didik dapat mengenali dan beradaptasi dengan lingkungan baru.

Pelaksanaan kegiatan orientasi siswa baru akan mengandung pendidikan seksual dengan membagi kelompok antara kelompok siswa laki-laki dan siswa perempuan. Pengaturan pengelompokan ini didasarkan pada larangan ajaran Islam tentang ikbtilath yaitu pembauran dengan lawan jenis. Pembagian kelompok berdasarkan gender (jenis kelamin) ini merupakan salah satu bentuk pembiasaan pengenalan pola interaksi sosial yang dihalalkan dalam Islam kaitannya aturan interaksi dengan lawan jenis.

Pada tahap ini pihak sekolah memiliki kesempatan untuk mensosialisasikan berbagai aturan tata tertib sekolah kepada semua peserta didik baru. Sosialisasi aturan tata tertib sekolah pada peserta didik baru sangat penting untuk dilaksanakan karena fungsinya untuk mengatur perilaku peserta didik selama di sekolah. Aturan tata tertib sekolah yang mengandung nilai-nilai pendidikan seksual yang dapat diterapkan di sekolah adalah aturan tentang pakaian seragam sekolah yang menutupi aurat, baik seragam laki-laki maupun seragam perempuan. Pembiasaan memakai pakaian seragam yang menutupi aurat secara tidak langsung mengajarkan pada peserta didik untuk terbiasa menutupi auratnya dalam kehidupan sehari-hari.

Aturan tata tertib lain yang mengandung nilai-nilai pendidikan seksual adalah larangan memakai perhiasan di sekolah. Larangan ini adalah representasi dari pengamalan dari QS An-Nur ayat 31. Larangan pemakaian perhiasan di sekolah ini mengajarkan pada peserta didik, khususnya siswi, agar tidak menampakkan perhiasannya pada selain mahramnya sekaligus menanamkan anak untuk tampil tidak mencolok dengan perhiasannya, karena perhiasan merupakan salah satu pintu masuk bangkitnya hasrat seksual dari lawan jenis yang melihatnya. Bahkan perlu sekolah memberlakukan aturan tegas yang secara langsung memberikan tindakan hukuman berat bagi peserta didik yang melakukan tindakan perzinahan, pelecehan seksual, penyimpangan seksual, dan pelanggaran yang semisalnya. Penegakan aturan tata tertib tersebut sangat 
efektif sebagai tindakan preventif dalam menaggulangi pelanggaran seksual di lingkungan sekolah yang rentan terjadi.

2. Proses pembelajaran

Inti kegiatan belajar di sekolah terletak pada proses pembelajaran. Demikian pula dengan pelaksanaan pendidikan seksual sangat efektif dan memegang peranan penting diberikan pada peserta didik yang terintegrasi ke dalam berbagai program pembelajaran di kelas maupun di luar kelas. Ada beberapa pengelolaan proses pembelajaran yang dapat dimaksimalkan untuk memasukkan nilai-nilai pendidikan seksual pada peserta didik, dimana pengelolaan ini tetap mengacu pada kaidah dan langkah-langkah pengelolaan proses pembelajaran yang kerap di aplikasikan dalam manajemen peserta didik secara umum, yaitu: pengelolaan pengelompokan siswa dalam rombongan belajar (kelas), penentuan metode pembelajaran, dan pengelolaan program pembelajaran.

Tahapan pengelolaan pembelajaran pertama yang dapat dimaksimalkan dalam pembinaan pendidikan seksual peserta didik adalah pengelolaan pengelompokan siswa berdasarkan jenis kelamin (gender grouping). Aplikasi pengelompokan ini sudah lazim dioperasionalkan oleh berbagai lembaga pendidikan Islam seperti madrasah dan pondok pesantren, sekaligus menjadi pembeda dengan pengelompokan siswa di lembaga pendidikan umum. Pengelompokan siswa di kelas berdasarkan jenis kelamin ini memiliki peranan yang sangat strategis dalam mendukung pembinaan pendidikan seksual peserta didik, karena di dalamnya mengandung salah satu ajaran Islam yang pokok, yaitu larangan dari ikhtilath (pembauran dengan lawan jenis).

Berbagai penelitian dan argumentasi dari para ahli pendidikan Islam menguatkan pengelompokan ini, diantaranya hasil riset dari Hakim Ben Londsi yang menyatakan bahwa anak-anak di Amerika mengalami masa pebertas sebelum waktu normalnya, libido seksualnya mengalami peningkatan bahkan sejak usia dini. Terhitung dari 312 anak perempuan yang dijadikan sampel, hasilnya 225 anak telah mencapai usia baligh di usia 11-15 tahun. Di usia tersebut anak-anak perempuan tersebut telah memiliki kecenderungankecenderungan seksual (libido) yang normalnya baru dirasakan oleh anak 
perempuan di usia 18 tahun ke atas. Dia juga menyebutkan dalam penelitiannya tersebut bahwa $45 \%$ anak-anak usia sekolah telah menjalin hubungan seksual sebelum lulus sekolah. Persentase tersebut ternyata terus meningkat dan berlanjut ke jenjang pendidikan tinggi. ${ }^{24}$

Dikuatkan oleh Adit Hocker di dalam bukunya, "Aturan Seksual", menyatakan bahwa gadis berusia 7 atau 8 tahun di kalangan pelajar yang melakukan tindakan mesum dengan anak laki-laki bukanlah sesuatu yang asing lagi. Menurut fenomena-fenomena tersebut, pengelompokan siswa di kelas berdasarkan jenis kelamin (gender grouping) sangat urgen dilakukan sebagai pembiasaan bagi para peserta didik untuk menghindari ikbtilath (berbaur dengan lawan jenis) dimana pembauran tersebut merupakan sebab berbagai penyimpangan dan permasalahan seksual yang kerap terjadi di sekolah.

Namun demikian, pengelompokan ini tidak lepas dari kritik oleh ahli pendidikan lainnya, pengelompokan siswa yang didasarkan pada jenis kelamin bersiko menimbulkan beberapa permasalahan, diantaranya (1) rendahnya ketercapaian tugas perkembangan peserta didik; (2) peserta didik mengalami kesulitan dalam menjalin hubungan sosial karena tidak ada interaksi dengan lawan jenis; (3) peserta didik cenderung melakukan aktivitas yang berlainan dengan peran sosialnya; (4) rentan muncul isu yang berbau rasis; (5) peserta didik rentan mengalami disorientasi seksual. ${ }^{25}$

Namun berbagai kritik tersebut mengerucut pada satu permasalahan, yaitu terhambatnya interaksi sosial. Jika itu permasalahannya, maka hal itu dapat diberikan solusi dengan mengoptimalkan peran guru bimbingan konseling untuk memberikan bimbingan yang mengarah pada peningkatan interaksi sosial tanpa berlawanan dengan hukum Islam terkait larangan ikbtilath. Di samping itu, peran keluarga dalam mendampingi anaknya di lingkungannya sangat berkontribusi dalam aspek meningakatkan kemampuan interaksi sosial anak di lingkungannya masing-masing. Kritikan tersebut juga dapat dijawab

${ }^{24}$ Muhammad Nur Abdul Hafizh Suwaid, Manhaj al-Tarbiyyat al-Nabawiyyat lil ath-Thifl. (Mesir: Daar alWafa' al-Manshurah, 2013), 380

${ }^{25}$ Peni Ramanda dan Imalatul Khairat, "Perbedaan Kematangan Sosial Siswa yang Berasal dari Sekolah Homogen dan Sekolah Heterogen”, Jurnal Kajian Bimbingan dan Konseling, Volume 2, Nomor 4, 2017, 148 156 
dengan pendekatan ilmu ushul fiqh, bahwa terdapat kaidah ushul yang berbunyi “dar'ul mafaasid aulaa min jalbil mashaalih" yang artinya menghilangkan kemudharatan itu lebih diutamakan daripada mengambil manfaat. Sehubungan dengan hal ini, menghindari kemudharatan yang berupa peluang terjadinya berbagai permasalahan seksual pada peserta didik lebih diutamakan daripada manfaat yang dapat diterima berupa kemampuan interaksi sosial anak yang baik tersebut.

Pengelolaan kedua dalam proses pembelajaran yang dapat dimaksimalkan untuk diintegrasikan dengan pendidikan seksual adalah pengelolaan program pembelajaran. Program pembelajaran erat kaitannya dengan manajemen kurikulum. Oleh Karena itu, dibutuhkan penyesuaian kurikulum yang dapat mengintegrasikan kurikulum sekolah dengan pembinaan pendidikan seksual anak. Diantaranya memasukkan nilai-nilai pendidikan seksual ke dalam mata pelajaran formal, khususnya pada mata pelajaran Biologi, Sosiologi, Akhlak, dan Fiqih.

Mata pelajaran Biologi dapat memperkenalkan peserta didik terkait materi pengenalan nama-nama organ tubuh, termasuk di dalamnya vagina, testis, penis, dan payudara; serta materi seputar reproduksi. Mata pelajaran Sosiologi dapat memperkuat pemahaman anak tentang interaksi sosial yang mengatur bagaimana cara interaksi yang baik dengan lawan jenis dan sesama jenis, serta mengidentifikasi teman yang baik dan buruk untuk dirinya. Mata pelajaran Akhlak akan membahas terkait materi etika berinteraksi dengan mahram dan bukan mahram, perilaku-perilaku seksual menyimpang yang harus dihindari dan perilaku-perilaku mana saja yang harus dilakukan pada masa remaja yang sangat rentan sebagai pelaku atau korban penyimpangan dan pelecehan seksual. Mata pelajaran Fiqih dapat mengupas materi tentang batasan usia baligh, hukum pernikahan, dan hukum zina.

Pengelolaan ketiga terkait pengelolaan metode pengajaran dalam menyampaikan nilai-nilai pendidikan seksual pada peserta didik. Pendidikan seksual membutuhkan metode yang tepat agar pesan yang akan disampaikan dapat difahami dengan baik oleh peserta didik. Metode ini disesuaikan dengan 
materi mata pelajaran, usia peserta didik, dan tempat berlangsungnya pendidikan seksual. Metode-metode tersebut diantaranya:

a) Ekspositori/Ceramah, metode ini sangat tepat diterapkan kepada peserta didik usia di bawah 10 tahun, karena di usia tersebut anak membutuhkan pengarahan dan penanaman prinsip mental dan pengetahuan secara lisan oleh pendidik. Misalnya pemberian nasihat tentang kodrat wanita yang harus menutup auratnya dengan cara memakai hijab agar tidak memancing syahwat bagi laki-laki yang melihatnya.

b) Diskusi, metode ini sangat sesuai untuk menampung rasa ingin tahu peserta didik terkait permasalahan seksual. Keingintahuan tersebut tersalurkan melalui berbagai pertanyaan yang terlontar pada pendidik. Metode ini merupakan pola komunikasi dua arah yang efektif karena pendidik dapat langsung menjawab pertanyaan dari peserta didik. Misalnya ada yang bertanya tentang fungsi alat kelamin, maka guru menjawabnya dengan intonasi yang santai dan biasa layaknya menyebut organ tubuh lainnya seperti mata, hidung, telinga dan hindari pengucapan dengan perasaan risih dan berbisik. Pendidik tidak perlu resah dan khawatir dengan pertanyaan seks anak, karena di tahap awal pendidikan seks, bagi mereka sama seperti mereka menanyakan masalah bagaimana pesawat bisa terbang dan mobil bisa berjalan.

c) Metode keteladanan, metode ini berupa pemberian contoh yang baik pada peserta didik terkait bagaimana seorang pendidik mengaplikasikan teori dan materi terkait pendidikan seksual yang telah diajarkan pada siswanya. Misalnya guru benar-benar memakai hijab yang baik sesuai tuntunan syariat yaitu memakai hijab hingga menutupi dada yang dapat diteladani dan dicontoh oleh siswinya.

d) Metode pembiasaan, metode ini berupaya membiasakan anak berfikir, bersikap, dan berperilaku sesuai dengan ajaran Islam. Penerapan metode pembiasaan ini efektif untuk peserta didik yang berusia kecil, karena mereka memiliki rekam ingatan yang kuat dan keadaan kepribadian yang belum matang. Sehingga membiasakan mereka dengan kebiasaan-kebiasaan baik sejak kecil dapat membantu memperbaiki perilaku mereka di masa dewasa. 


\section{Kontribusi Manajemen Peserta Didik Terhadap Pendidikan Seksual}

Berkaitan dengan pembiasaan pendidikan seksual misalnya membiasakan anak menutup pintu kamar mandinya ketika mereka buang air agar terbangun budaya malu sejak kecil dan kebiasaan menutup auratnya, membiasakan anak meminta izin (isti'dzan) ketika ia akan memasuki kamar orang tuanya agar terhindar dari pemandangan aktivitas orang tuanya yang belum layak dilihat oleh anak seusianya.

3. Bimbingan dan Monitoring

Pelaksanaan pendidikan seksual pada peserta didik memerlukan peran aktif tenaga professional di bidang konseling. Oleh karena itu pihak sekolah harus memberdayakan guru bimbingan dan konseling yang tersedia di sekolah untuk membantu, mendampingi dan memonitor pelaksanaan pendidikan seksual pada peserta didik. Selanjutnya monitoring pelaksanaan pendidikan seksual merupakan salah satu rangkaian dalam proses pendidikan seksual anak untuk mengetahui kualitas keberhasilan pendidikan tersebut. Seluruh stakeholder yang ada di sekolah tersebut seperti kepala sekolah, wakil kepala sekolah bidang kesiswaan, wali kelas, guru mata pelajaran, guru bimbingan dan konseling bahkan sampai orang tua diharapkan ikut berkontribusi aktif dalam kegiatan monitoring ini, sehingga pihak sekolah dapat memberikan evaluasi dan pengembangan pendidikan seksual anak di lingkungan sekolah.

\section{Kesimpulan}

Selama ini di berbagai literatur pendidikan Islam, pembinaan pendidikan seksual pada anak merupakan tanggung jawab orang tua di rumah, namun saat ini sekolah juga bisa menjalankan peranan tersebut. Melalui manajemen peserta didik pendidikan Islam yang terorganisir dan terencana, kegiatan pembinaan pendidikan seksual pada peserta didik dapat diaplikasikan di sekolah, tidak hanya di rumah. Proses pelaksanaan pendidikan seksual pada peserta didik dapat dilaksanakan dengan tiga tahapan kegiatan, yaitu tahapan penerimaan peserta didik baru, proses pembelajaran, bimbingan dan monitoring. Pada tahapan pertama melalui pengelolaan kegiatan orientasi peserta didik baru yang dibagi menjadi kelompok laki-laki dan perempuan, peserta didik baru dibiasakan untuk tidak melakukan ikhtilath (berbaur) dengan lawan jenis. Kegiatan ini juga harus dimanfaatkan pihak sekolah untuk 
mensosialisasikan aturan-aturan sekolah yang mengandung nilai-nilai pendidikan seksual.

Pengelolaan proses pembelajaran merupakan tahapan kedua dalam proses pendidikan seksual anak sekaligus menjadi bagian integaral dalam pendidikan ini. Pengelolaan proses pembelajaran ini berupa pengelolaan pengelompokan siswa di kelas berdasarkan jenis kelamin (gender grouping); penentuan metode pembelajaran melalui metode ekspositori, metode diskusi, metode keteladanan, dan metode pembiasaan; serta pengelolaan program pembelajaran dengan mengintegrasikan nilainilai pendidikan seksual ke dalam mata pelajaran formal seperti mata pelajaran Biologi, Sosiologi, Akhlak, dan Fiqih.

Tahapan selanjutnya adalah melaksanakan bimbingan terstruktur terkait pembinaan pendidikan seksual di bawah pengawasan guru bimbingan dan konseling. Tahapan terakhir dalam rangkaian proses pendidikan seksual di sekolah adalah kegiatan monitoring yang melibatkan seluruh stakeholder yang ada di lingkungan sekolah seperti kepala sekolah, wakil kepala sekolah bidang kesiswaan, wali kelas, guru mata pelajaran, guru bimbingan dan konseling bahkan sampai orang tua.

\section{Daftar Rujukan}

Al-Munawwir, Ahmad Warson. Kamus Al-Munawwir Arab-Indonesia Terlengkap. Yogyakarta: Pustaka Progresif, 1997.

Ath-Thawil, Utsman. Ajaran Islam tentang Fenomena Seksual. Jakarta: Raja Grafindo Persada, 2000.

Badrudin. Manajemen Peserta Didik. Jakarta: Indeks, 2014.

Bukhori, Muhammad. Islam dan Adab Seksual, Solo: Amzah, 2001.

Departemen Pendidikan Nasional Republik Indonesia. Manajemen Peningkatan Mutu Berbasis Sekolah. Jakarta: Direktorat SLTP, 2001.

E. Mulyasa. Manajemen Berbasis Sekolah; Konsep, Strategi, dan implementasi, Bandung: Rosdakarya, 2004.

Irham, Muhammad. Psikologi Pendidikan; Teori dan Aplikasi dalam Proses Pembelajaran, Yogyakarta: Ar-Ruzz Media.

Juliadarma, Minggusta. Pencegahan Kenakalan Anak Menurut Abdullah Nashih 'Ulwan. Jurnal Istighna Volume 2, Nomor 2 (2019). 
Minarti, Sri. Manajemen Sekolah; Mengelola Lembaga Pendidikan Secara Mandiri. Yogyakarta: Ar-Ruzz Media, 2012.

Mukti, Ali. Pendidikan Seks Untuk Anak Usia Dini Perspektif Islam, Jurnal Harkat Volume 12, nomor 2 (2016).

Nurlaili. Pendidikan Seks Pada Anak, Jurnal Marwah, Volume 10, nomor 1, (2011). Qomar, Mujamil. Manajemen Pendidikan Islam; Strategi Baru Pengelolaan Lembaga Pendidikan Islam. Jakarta: Erlangga, 2017.

Ramanda, Peni. Perbedaan Kematangan Sosial Siswa yang Berasal dari Sekolah Homogen dan Sekolah Heterogen. Jurnal Kajian Bimbingan dan Konseling, Volume 2 Nomor 4 (2017).

Sagala, Syaiful. 2009. Administrasi Pendidikan Kontemporer. Bandung: Alfabeta, 2009

Sirojudin, Didin. Aksiologi Ilmu Pengetahuan Manajemen Pendidikan Islam. Jurnal Al-Idaroh, Volume 4 Nomor 2 (2020).

Sugihartono. Psikologi Pendidikan. Yogyakarta: UNY Press, 2007.

Sunarto. 2008. Perkembangan Peserta Didik. Jakarta: Rineka Cipta, 2008.

Suruni. Manajemen Pendidikan. Bandung: Alfabeta, 2009.

Suwaid, Muhammad Nur Abdul Hafizh. Manhaj al-Tarbiyyat al-Nabawiyyat lil athThifl, Mesir: Daar al-Wafa' al-Manshurah, 2013.

Ulwan, Abdullah Nashih. 2010. Mas'uliyyat al-Tarbiyyah al-Jinsiyyah, Beirut: Daar alSalaam, 2010. 